\title{
THE IMPACT OF THE CORONAVIRUS PANDEMIC ON MENTAL HEALTH AMONG AL AIN UNIVERSITY STUDENTS IN LIGHT OF SOME DEMOGRAPHIC VARIABLES
}

\author{
Youssef Abuhmaidan \& Salwa Al-Majali \\ Department of Humanities and Social Sciences, Al Ain University, Al Ain, UAE
}

received: 15.6.2020;

revised: 7.8.2020;

accepted: 23.10 .2020

\begin{abstract}
SUMMARY
Background: This study aimed to know the effect of the Corona pandemic on mental health among Al Ain University students and its relationship to some demographic variables (gender, academic level age, college, and marital status).

Subject and method: The sample of the study consisted of (258) male and female students from Al Ain University students from humanities and scientific colleges. The modified Mental Health Scale: R S CL-90 Symptoms Check List was used, which was developed by Derogatis, Lipman, and Linocovi, it included (74) items divided into seven dimensions: physical symptoms, obsessive-compulsive disorder, reactive sensitivity, depression, anxiety, enmity, and fear anxiety, after modifying it for the purposes of the study.

Results: The results showed that the level of mental health of the sample as a whole was very high. The results also showed that the level of mental health was low for females when compared to males. The second-year students were less in the level of mental health compared to the rest of the levels. For students who were less than twenty years old, the level of mental health was low compared to those over twenty years old. No differences were found in the level of mental health among students of scientific and human colleges. As for the social situation, the level of mental health among single students was low compared to married people.

Conclusion: The results of the study indicate that the higher the average mental problems (the dimensions of the mental health level), the lower of the mental health problems. Although the level of mental health was varied according to the demographic variables.
\end{abstract}

Key words: Corona pandemic - mental health - demographic variables

$* * * * *$

\section{INTRODUCTION}

The world has woken up early this year to the news of the spread of the Coronavirus, which started in China and has spread to almost every country in the world, and the people of the whole world did not expect that the disease would spread so quickly and so severely and that the number of deaths would be so. Coronaviruses are a wide range of viruses that may cause disease in animals and humans. It is known that several coronaviruses cause human respiratory diseases, the severity of which ranges from the common cold to more severe diseases such as the Middle East respiratory syndrome. The Covid-19 disease is an infectious disease caused by the last detected virus of the Coronavirus. There was no knowledge of this new virus and its disease before it began spreading in Wuhan, China, in December 2019. Covid-19 has now turned into a pandemic affecting many countries of the world (WHO 2019).

This virus has caused fear and anxiety, depression, emotional sensitivity, phobia, and various symptoms of mental disorders that vary in intensity and severity. This means that the level of mental health that we always seek may be affected by this crisis, and human mental health in all parts of the earth is threatened. It is known that the level of mental health is closely related to the level of physical immunity, so mental immunity is a strong foundation upon which the body's immunity is based and helps in fighting disease more effectively (Ohrnbergera et. al. 2017). We have all noticed the level of fear and anxiety that have become one of the manifestations that we see in people. There is no doubt that mental health is a basic requirement that every person seeks to achieve to live in balance in this life.

The World Health Organization (WHO) defines mental health as not merely devoid of symptoms of mental illness but rather a positive state of physical, psychological, and social comfort represented by enjoying mental health, sensory integrity, and proper behavior (Qabbani 2017). Therefore, we find that mental health includes a feeling of happiness with oneself and others, a feeling of contentment, reassurance, security, mental integrity, appetite for life, a feeling of strength, activity, and positive adaptation to the requirements of life. Qabbani (2017) indicates that a high level of mental health appears clearly in a person who has characteristics such as efficiency, emotional balance, good behavior, personality integrity, and ability to face crises and has a high level of mental health. The news about suffering from the symptoms and impact of this disease increases a person's fear and affects his level of mental health.

There are no doubt that physical and mental health controls the quality of life. There are multiple factors that affect a person's mental health, including the necessity to satisfy the physiological needs, the balance 
of personality and the general form of the individual, as well as the individual with physical diseases, which greatly affect human life, and the healthy mental ability to help him make decisions (Radwan 2002). The conditions surrounding a person also affect his mental health, one of the most important things that help us maintain positive mental health is a positive adaptation (Abuhmaidan 2019).

Tourous \& Keshavan (2020) indicated that the initial reports that suggested the importance of attention to mental health for patients with Coronavirus were not given much attention. Few of the relevant authorities have applied this in China, as noted by (Liu et al. 2020). Coronavirus has threatened human health. In this study conducted on some of Al Ain University students, the researchers would like to know how this virus affected their mental health.

In a study of Mckay et al. (2020), it aimed to find out the effect of the Coronavirus on feelings of disgust, sensitivity, fear, and emotional responses that affect body immunity. The study sample consisted of 908 Chinese students in the two-month study. Participants filled out a measure of sensitivity, anxiety, disgust, and fear of catching an infection. The results showed a moderate relationship between feelings of disgust, sensitivity, and fear of infection with the Coronavirus. The results also supported the effect of the Coronavirus on the behavioral immune system level.

Tanguy et al. (2020) also conducted a study aimed at knowing the relationship between the presence or absence of patients with coronavirus in a specific area (Close setting) and the level of psychological disturbance in a sample of an average age between 15-29. A number of 16402 responded to the questionnaire which focused on the last three questions in the scale that measure the presence of mental disorder, which is "how many times during the last thirty days you were nervous" and the second "how many times during the thirty days you felt tired" and the third "how many times you felt depressed and nothing adjust your mood. The results showed that the total who were 60 years old and had corona disease and were in a specific area of treatment had experienced a high level of psychological pressure regardless of gender. The study recommended the necessity of providing psychological support to the family and those surrounding the individual.

Wenjun et al. (2020) also conducted a study aimed at identifying the psychological pressures associated with the epidemic of the Coronavirus. The study sample consisted of $(7,143)$ students from Changzhi Medical College who were chosen using cluster samples. Participants completed a GAD-7 general anxiety disorder questionnaire. The results indicated that $0.9 \%$ of the respondents had severe anxiety, $2.7 \%$ of moderate anxiety, and $21.3 \%$ of mild anxiety. Moreover, living in urban areas, stable family income, and living with parents were protective factors against anxiety. The results also indicated that the presence of relatives or acquaintances with COVID-19 is a risk factor for increasing anxiety among the study sample. The results of the correlation analysis also indicated that the economic effects, the effects on daily life, as well as the delay in academic activities, are positively linked to the symptoms of anxiety $(\mathrm{P}<0.001)$. However, social support was negatively associated with the level of anxiety $(\mathrm{P}<0.001)$. The study recommended monitoring the mental health of college students during epidemics.

This study aims to know the impact of the Corona pandemic on the level of mental health in its various dimensions among university students and its relationship to some demographic variables such as gender, academic level, age, college, and marital status. It also aims to know the differences in the level of impact attributed to demographic variables.

\section{METHODS}

\section{The Population of the Study and its Sample}

The population of the study consists of all undergraduate students at Al Ain University who are enrolled in the second semester of the academic year 2019/2020, in its two campuses at Al-Ain and Abu Dhabi. The sample of the study consisted of (258) male and female students who responded to the scale electronically.

\section{Ethical considerations}

This study was approved by Research Ethics committee at al Ain University. The students' participation was strictly voluntary. Informed consent of the participants was obtained prior to study inclusion and no personal data of the participants are reported.

\section{The Study Tools}

The modified Mental Health Scale was used: R S CL-90 Symptoms Check List. Developed by Derogatis, Lipman, and Linocovi, which included 90 items divided into nine dimensions: physical symptoms, obsessivecompulsive disorder, reactive sensitivity, depression, anxiety, enmity, fear anxiety (phobia or paranoia and psychosis), in this study, the paranoia and psychotic dimensions were excluded to keep the scale seven dimensions, and it included 74 items, each of the items of the study tool corresponds to a list that carries the following phrases: (I never suffer (0-0.79) - (2 suffer in a low degree (1.59-0.80) - (3 suffer in a moderate degree (2.39-1.6) - (4 suffer in a high degree (3.19-2.40) - (5 suffer in a very high degree 3.20-4).

\section{The validity and reliability of the study tool}

The researchers confirmed the validity of the study tool through internal consistency. The values of correlation coefficients for the axes in the total degree range between 0.869 and 0.957 , which means that there is a high degree of internal consistency. To verify the 
reliability of the questionnaire, the researchers used the Cronbach Alpha equation. The values of the reliability coefficients are all high, as the values of the coefficients of reliability in the questionnaire ranged between 0.754 0.915 and the total reliability coefficient of the questionnaire reached 0.978 , these values of reliability coefficients indicate the validity of the application resolution and the reliability of its results.

\section{Procedure}

A cross-sectional online scale was distributed during the whole month of March 2020. The scale was distributed to all students at Al Ain University through university website. All participants provided informed consent electronically prior to registration. Only students who accepted to participate were taken to the scale.

\section{RESULTS}

\section{Demographic characteristics}

The demographic data include gender (male or female), college, academic levels (first year, second year, third year, and fourth year), age (less than 20 years old, or more than 20 years old) and social status (single or married). A sample of 258 participants, including 61 (23.6\%) males and 197 (76.4\%) females, completed the scale. Demographic characteristics are expresses in Table 1.

\section{Statistical analysis}

All data were entered and analyzed using SPSS $\odot$ version 23 (IBM Corp, Armonk, NY, USA). Variables were presented as means \pm standard deviations (SDs) and ranking of mental health scale dimension. One-way analysis of variance was used to compare the means of the variables of mental health level and their dimensions according to the variable of the academic level. Scheffe test was used to identify the trend of differences in the mean levels of mental health degree and its dimensions according to the academic level variable. Analysis of significance was used to compare the mean levels of mental health degrees with their dimensions according to gender, age, college, and social status. and the "T" test to determine the significance of the differences in the average levels of mental health degrees and their dimensions in the study sample according to the variables (age, gender, college, marital status). $\mathrm{P}$ value of $<0.05$ considered to be significant.

Table 1. The distribution of the study sample individuals according to their demographic variables

\begin{tabular}{lccc}
\hline Variables & Frequency & Percentage & Total \\
\hline Gender & 61 & & 258 \\
$\quad$ Males & 197 & $23.6 \%$ & \\
Females & & $76.4 \%$ & 258 \\
Academic level & 49 & $19 \%$ & \\
$\quad$ First & 57 & $22.1 \%$ & \\
Second & 59 & $22.9 \%$ & \\
$\quad$ Third & 83 & $36 \%$ & 258 \\
$\quad$ Fourth & & & \\
College & 197 & $76.4 \%$ & 258 \\
$\quad$ Human sciences & 61 & $23.60 \%$ & \\
$\quad$ Applied Sciences & 23 & & \\
Age & 235 & $91.9 \%$ & \\
$\quad$ Less than 20 years & & & \\
$\quad$ More than 20 years & 156 & $60.5 \%$ & \\
Social status & 102 & $39.5 \%$ & \\
$\quad$ Single & & & \\
$\quad$ Married & &
\end{tabular}

Table 2. Mean, Standard Deviations, and Ranking of Mental Health Scale Dimensions

\begin{tabular}{lcccc}
\hline The axis & Mean & Standard deviation & Ranking & Level of psychological problems \\
\hline Obsessive-compulsive disorder & 1.04 & 0.78 & 1 & Low \\
Depression & 0.90 & 0.78 & 2 & Low \\
Interactive sensitivity & 0.80 & 0.78 & 3 & Low \\
Anxiety & 0.75 & 0.82 & 4 & Very low \\
Physical symptoms & 0.70 & 0.68 & 5 & Very low \\
Enmity & 0.60 & 0.66 & 6 & Very low \\
Phobia & 0.58 & 0.66 & 7 & Very low \\
Mental health problems as a whole & 0.79 & 0.68 & & \\
\hline
\end{tabular}




\section{The mental health level of the study sample}

The mean, and standard deviations for the dimensions of mental health were calculated. Table 2 shows the mean for those dimensions. It can be seen from Table 2 when looking at the components of mental health, we find that obsessive-compulsive disorder, depression, and reactive sensitivity were higher than other factors, as they were low, while the rest were very low. Obsessive-compulsive disorder ranked first in terms of decline, where the arithmetic average 1.04, which is the highest low value in the list of mental health, we note that obsessive-compulsive disorder was the height and this is evident from the obsessive disorder that affects people from repeated caveats that may lead to disease when touching or contacting with others led to a high level of obsessive. Also, the high level of depression, with a mean 0.90 , maybe due to isolation, introverted, and distance from contact with others. Then the interactive sensitivity, which has an arithmetic average 0.80 . Then anxiety with an average of 0.75 and the physical symptoms dimension with an average of 0.70 , then enmity with an average of 0.60 , in the last rank, phobia with an average of 0.58 .

\section{The differences in mental health scores according to the demographic variables}

\section{The gender variable}

As with the gender variable (male and female) t-test analysis was used to compare the mean levels of mental health degrees with their dimensions according to the gender variable, and Table 3 shows the result of the t-test for the significance of the differences between the averages.

From Table 3 it is clear that there are statistically significant differences between the mean levels of mental health degrees with their dimensions (obsessive- compulsive disorder, depression, interactive sensitivity, anxiety, physical symptoms, hostility, fear anxiety (phobia), and mental health as a whole) among study members according to the gender variable, where the significance levels were $(0.00,0.003,0.024,0.00,0.001$, $0.033,0.002,0.00)$ respectively and they are indicative levels. Consequently, there are differences between male and female mean mental health degrees in their dimensions (obsessive-compulsive disorder, depression, reactive sensitivity, anxiety, physical symptoms, hostility, fear anxiety (phobia), and mental health as a whole) in favor of females with higher arithmetic mean.

\section{The academic level variable}

The academic level variable in this study was divided into four levels, therefore, the analysis of variance was used to compare the averages of the variables of mental health levels and their dimensions according to the variable of the academic level. Table 4 shows the result of the variance test for the significance of the differences between the averages.

It is clear from Table 4 that there are statistically significant differences in the mean levels of mental health with their dimensions (obsessive-compulsive disorder, depression, physical symptoms, and mental health as a whole) among study members according to the variable of the academic level where the significance levels were $(0.015,0.001,0.042,0.013)$ respectively, which are statistically significant levels. The following are the results of a Scheffe test to identify the trend of differences in the mean levels of mental health degrees and its dimensions according to the academic level variable. The differences that appeared between the averages of mental health degrees and their dimensions according to the variable of the academic level were as follows: In the Obsessive-Compulsive Dimension:

Table 3. Analysis of the significance of the differences between the averages of mental health degrees in their dimensions according to the gender variable

\begin{tabular}{|c|c|c|c|c|c|c|}
\hline Axis & Gender & $\mathrm{N}$ & Mean & Standard deviation & " $\mathrm{t}$ " value & Sig \\
\hline Obsessive-compulsive disorder & $\begin{array}{l}\text { Male } \\
\text { Female }\end{array}$ & $\begin{array}{r}61 \\
197\end{array}$ & $\begin{array}{l}0.425 \\
0.780\end{array}$ & $\begin{array}{l}0.470 \\
0.716\end{array}$ & -3.635 & $0.000 * *$ \\
\hline Depression & $\begin{array}{l}\text { Male } \\
\text { Female }\end{array}$ & $\begin{array}{r}61 \\
197\end{array}$ & $\begin{array}{l}0.785 \\
1.123\end{array}$ & $\begin{array}{l}0.695 \\
0.792\end{array}$ & -2.991 & $0.003 * *$ \\
\hline Interactive sensitivity & $\begin{array}{l}\text { Male } \\
\text { Female }\end{array}$ & $\begin{array}{r}61 \\
197\end{array}$ & $\begin{array}{l}0.599 \\
0.856\end{array}$ & $\begin{array}{l}0.710 \\
0.788\end{array}$ & -2.276 & $0.024^{*}$ \\
\hline Anxiety & $\begin{array}{l}\text { Male } \\
\text { Female }\end{array}$ & $\begin{array}{r}61 \\
197\end{array}$ & $\begin{array}{l}0.557 \\
1.003\end{array}$ & $\begin{array}{l}0.557 \\
0.809\end{array}$ & -4.016 & $0.000 * *$ \\
\hline Physical symptoms & $\begin{array}{l}\text { Male } \\
\text { Female }\end{array}$ & $\begin{array}{r}61 \\
197\end{array}$ & $\begin{array}{l}0.433 \\
0.845\end{array}$ & $\begin{array}{l}0.583 \\
0.864\end{array}$ & -3.483 & $0.001 * *$ \\
\hline Enmity & $\begin{array}{l}\text { Male } \\
\text { Female }\end{array}$ & $\begin{array}{r}61 \\
197\end{array}$ & $\begin{array}{l}0.443 \\
0.648\end{array}$ & $\begin{array}{l}0.523 \\
0.689\end{array}$ & -2.144 & $0.033^{*}$ \\
\hline Phobia & $\begin{array}{l}\text { Male } \\
\text { Female }\end{array}$ & $\begin{array}{r}61 \\
197\end{array}$ & $\begin{array}{l}0.351 \\
0.654\end{array}$ & $\begin{array}{l}0.463 \\
0.696\end{array}$ & -3.183 & $0.002 * *$ \\
\hline Mental health as a whole & $\begin{array}{l}\text { Male } \\
\text { Female }\end{array}$ & $\begin{array}{r}61 \\
197 \\
\end{array}$ & $\begin{array}{l}0.524 \\
0.871 \\
\end{array}$ & $\begin{array}{l}0.519 \\
0.705\end{array}$ & -3.550 & $0.000 * *$ \\
\hline
\end{tabular}

* Statistically significant for the significance level of $0.05 ; * *$ Statistically significant for the significance level of 0.01 
Table 4. Results of One-way analysis of variance of the significance of the differences in the mean degrees of mental health according to the academic level variable

\begin{tabular}{|c|c|c|c|c|c|c|}
\hline Axis & Source of variance & Sum of squares & Df & Mean of squares & "F" value & Sig \\
\hline $\begin{array}{l}\text { Obsessive-compulsive } \\
\text { disorder }\end{array}$ & $\begin{array}{l}\text { Between groups } \\
\text { Within groups } \\
\text { Total }\end{array}$ & $\begin{array}{r}4.8 \\
114.8 \\
119.7\end{array}$ & $\begin{array}{r}3 \\
254 \\
257\end{array}$ & $\begin{array}{l}1.6 \\
0.5\end{array}$ & 3.6 & $0.015^{*}$ \\
\hline Depression & $\begin{array}{l}\text { Between groups } \\
\text { Within groups } \\
\text { Total }\end{array}$ & $\begin{array}{r}10.4 \\
146.8 \\
157.2\end{array}$ & $\begin{array}{r}3 \\
254 \\
257\end{array}$ & $\begin{array}{l}3.5 \\
0.6\end{array}$ & 6.0 & $0.001 * *$ \\
\hline Interactive sensitivity & $\begin{array}{l}\text { Between groups } \\
\text { Within groups } \\
\text { Total }\end{array}$ & $\begin{array}{r}4.4 \\
150.6 \\
155.0\end{array}$ & $\begin{array}{r}3 \\
254 \\
257\end{array}$ & $\begin{array}{l}1.5 \\
0.6\end{array}$ & 2.5 & 0.060 \\
\hline Anxiety & $\begin{array}{l}\text { Between groups } \\
\text { Within groups } \\
\text { Total }\end{array}$ & $\begin{array}{r}4.7 \\
151.5 \\
156.1\end{array}$ & $\begin{array}{r}3 \\
254 \\
257\end{array}$ & $\begin{array}{l}1.6 \\
0.6\end{array}$ & 2.6 & 0.053 \\
\hline Physical symptoms & $\begin{array}{l}\text { Between groups } \\
\text { Within groups } \\
\text { Total }\end{array}$ & $\begin{array}{r}5.5 \\
169.1 \\
174.7\end{array}$ & $\begin{array}{r}3 \\
254 \\
257\end{array}$ & $\begin{array}{l}1.8 \\
0.7\end{array}$ & 2.8 & $0.042 *$ \\
\hline Enmity & $\begin{array}{l}\text { Between groups } \\
\text { Within groups } \\
\text { Total }\end{array}$ & $\begin{array}{r}2.7 \\
108.7 \\
111.4\end{array}$ & $\begin{array}{r}3 \\
254 \\
257\end{array}$ & $\begin{array}{l}0.9 \\
0.4\end{array}$ & 2.1 & 0.097 \\
\hline Phobia & $\begin{array}{l}\text { Between groups } \\
\text { Within groups } \\
\text { Total }\end{array}$ & $\begin{array}{r}2.7 \\
109.5 \\
112.2\end{array}$ & $\begin{array}{r}3 \\
254 \\
257\end{array}$ & $\begin{array}{l}0.9 \\
0.4\end{array}$ & 2.1 & 0.100 \\
\hline Mental health as a whole & $\begin{array}{l}\text { Between groups } \\
\text { Within groups } \\
\text { Total }\end{array}$ & $\begin{array}{r}5.0 \\
114.2 \\
119.1 \\
\end{array}$ & $\begin{array}{r}3 \\
254 \\
257 \\
\end{array}$ & $\begin{array}{l}1.7 \\
0.4\end{array}$ & 3.7 & $0.013 *$ \\
\hline
\end{tabular}

* Statistically significant at the significance level of $0.05 ; * *$ Statistically significant at the level of 0.01

It was between (those studying at the second level) and (those studying at the fourth level) for the benefit of (those studying at the second level) with a higher arithmetic average. In the depression dimension: It was between (those studying at the second level) and (those studying at the third level) in favor of those (who are studying at the second level) with a higher arithmetic average. There were also differences between (those studying at the second level) and (those studying at the fourth level) in favor of (those studying at the second level) with a higher arithmetic average. In the physical symptoms dimension: It was between (those studying at the second level) and (those studying at the third level) in favor of those (who are studying at the second level) with a higher arithmetic average. There were also differences between (those studying at the second level) and (those studying at the fourth level) in favor of (those studying at the second level) with a higher arithmetic average. In mental health as a whole: It was between (those studying at the second level) and (those studying at the fourth level) for the benefit of (those studying at the second level) with a higher arithmetic average. The results indicate that the students of the second year are the ones who have had a low level of mental health compared to the rest of the students from other levels and this result may be attributed to the fact that students at this stage are at the crossroads and anxiety and fear have become clear to them more than others as they have made their way when they are at the end of the second year, and they would like to move to the third year, which indicates the beginning of the completion of university studies.

\section{Age variable}

As the age variable in this study is divided into two parts: less than 20 years, 20 years or more, t-test analysis was used to compare the mean levels of mental health degrees with their dimensions according to the age variable. Table 5 shows the result of the $t-$ test to indicate the differences between averages.

It is clear from Table 5 that there are statistically significant differences between the mean levels of mental health levels with their dimensions (obsessivecompulsive disorder, depression, interactive sensitivity, anxiety, physical symptoms, hostility, fear anxiety (phobia), and mental health as a whole) among study members according to the gender variable, where the significance levels were $(0.009,0.001,0.023,0.004$, $0.005,0.00,0.01,0.002)$, respectively, which are significant levels. Consequently, there are differences between the ages of less than 20 years and the ages of 20 and more in the average levels of mental health with dimensions (obsessive-compulsive disorder, depression, reactive sensitivity, anxiety, physical symptoms, hostility, fear anxiety (phobia), and mental health as a whole) in favor of those under the age of less 20 years with the highest arithmetic mean. 
Table 5. Analysis of the significance of the differences between the mean levels of mental health degrees in their dimensions according to the age variable

\begin{tabular}{|c|c|c|c|c|c|c|}
\hline Axis & Age & $\mathrm{N}$ & Mean & Standard deviation & " $t$ " value & Sig \\
\hline $\begin{array}{l}\text { Obsessive-compulsive } \\
\text { disorder }\end{array}$ & $\begin{array}{l}\text { Less than } 20 \text { years } \\
20 \text { years and over }\end{array}$ & $\begin{array}{r}23 \\
235\end{array}$ & $\begin{array}{l}1.051 \\
0.661\end{array}$ & $\begin{array}{l}0.897 \\
0.650\end{array}$ & 2.648 & $0.009 * *$ \\
\hline Depression & $\begin{array}{l}\text { Less than } 20 \text { years } \\
20 \text { years and over }\end{array}$ & $\begin{array}{r}23 \\
235\end{array}$ & $\begin{array}{l}1.535 \\
0.995\end{array}$ & $\begin{array}{l}0.858 \\
0.759\end{array}$ & 3.216 & $0.001 * *$ \\
\hline Interactive sensitivity & $\begin{array}{l}\text { Less than } 20 \text { years } \\
20 \text { years and over }\end{array}$ & $\begin{array}{r}23 \\
235\end{array}$ & $\begin{array}{l}1.145 \\
0.761\end{array}$ & $\begin{array}{l}1.059 \\
0.738\end{array}$ & 2.279 & $0.023 *$ \\
\hline Anxiety & $\begin{array}{l}\text { Less than } 20 \text { years } \\
20 \text { years and over }\end{array}$ & $\begin{array}{r}23 \\
235\end{array}$ & $\begin{array}{l}1.344 \\
0.854\end{array}$ & $\begin{array}{l}1.056 \\
0.735\end{array}$ & 2.922 & $0.004 * *$ \\
\hline Physical symptoms & $\begin{array}{l}\text { Less than } 20 \text { years } \\
20 \text { years and over }\end{array}$ & $\begin{array}{r}23 \\
235\end{array}$ & $\begin{array}{l}1.204 \\
0.703\end{array}$ & $\begin{array}{l}1.059 \\
0.786\end{array}$ & 2.823 & $0.005^{* *}$ \\
\hline Enmity & $\begin{array}{l}\text { Less than } 20 \text { years } \\
20 \text { years and over }\end{array}$ & $\begin{array}{r}23 \\
235\end{array}$ & $\begin{array}{l}1.138 \\
0.547\end{array}$ & $\begin{array}{l}0.945 \\
0.601\end{array}$ & 4.240 & $0.000 * *$ \\
\hline Phobia & $\begin{array}{l}\text { Less than } 20 \text { years } \\
20 \text { years and over }\end{array}$ & $\begin{array}{r}23 \\
235\end{array}$ & $\begin{array}{l}0.919 \\
0.550\end{array}$ & $\begin{array}{l}1.010 \\
0.609\end{array}$ & 2.589 & $0.010^{*}$ \\
\hline Mental health as a whole & $\begin{array}{l}\text { Less than } 20 \text { years } \\
20 \text { years and over }\end{array}$ & $\begin{array}{r}23 \\
235 \\
\end{array}$ & $\begin{array}{l}1.212 \\
0.747\end{array}$ & $\begin{array}{l}0.906 \\
0.642 \\
\end{array}$ & 3.179 & $0.002 * *$ \\
\hline
\end{tabular}

* Statistically significant for the significance level of $0.05 ; * *$ statistically significant for the significance level of 0.01

Table 6. Analysis of the significance of the differences between the averages of mental health degrees in their dimensions according to the college variable

\begin{tabular}{|c|c|c|c|c|c|c|}
\hline Axis & College & $\mathrm{N}$ & Mean & Standard deviation & "t $t$ " value & Sig \\
\hline $\begin{array}{l}\text { Obsessive-compulsive } \\
\text { disorder }\end{array}$ & $\begin{array}{l}\text { Human college } \\
\text { Scientific college }\end{array}$ & $\begin{array}{r}197 \\
61\end{array}$ & $\begin{array}{l}0.686 \\
0.727\end{array}$ & $\begin{array}{l}0.675 \\
0.709\end{array}$ & -0.410 & 0.682 \\
\hline Depression & $\begin{array}{l}\text { Human college } \\
\text { Scientific college }\end{array}$ & $\begin{array}{r}197 \\
61\end{array}$ & $\begin{array}{l}1.042 \\
1.048\end{array}$ & $\begin{array}{l}0.777 \\
0.806\end{array}$ & -0.052 & 0.959 \\
\hline Interactive sensitivity & $\begin{array}{l}\text { Human college } \\
\text { Scientific college }\end{array}$ & $\begin{array}{r}197 \\
61\end{array}$ & $\begin{array}{l}0.780 \\
0.845\end{array}$ & $\begin{array}{l}0.743 \\
0.882\end{array}$ & -0.572 & 0.568 \\
\hline Anxiety & $\begin{array}{l}\text { Human college } \\
\text { Scientific college }\end{array}$ & $\begin{array}{r}197 \\
61\end{array}$ & $\begin{array}{l}0.888 \\
0.928\end{array}$ & $\begin{array}{l}0.758 \\
0.850\end{array}$ & -0.348 & 0.728 \\
\hline Physical symptoms & $\begin{array}{l}\text { Human college } \\
\text { Scientific college }\end{array}$ & $\begin{array}{r}197 \\
61\end{array}$ & $\begin{array}{l}0.751 \\
0.734\end{array}$ & $\begin{array}{l}0.818 \\
0.852\end{array}$ & 0.139 & 0.889 \\
\hline Enmity & $\begin{array}{l}\text { Human college } \\
\text { Scientific college }\end{array}$ & $\begin{array}{r}197 \\
61\end{array}$ & $\begin{array}{l}0.579 \\
0.667\end{array}$ & $\begin{array}{l}0.646 \\
0.699\end{array}$ & -0.912 & 0.363 \\
\hline Phobia & $\begin{array}{l}\text { Human college } \\
\text { Scientific college }\end{array}$ & $\begin{array}{r}197 \\
61\end{array}$ & $\begin{array}{l}0.615 \\
0.478\end{array}$ & $\begin{array}{l}0.678 \\
0.596\end{array}$ & 1.420 & 0.157 \\
\hline Mental health as a whole & $\begin{array}{l}\text { Human college } \\
\text { Scientific college }\end{array}$ & $\begin{array}{r}197 \\
61 \\
\end{array}$ & $\begin{array}{l}0.785 \\
0.801 \\
\end{array}$ & $\begin{array}{l}0.671 \\
0.718 \\
\end{array}$ & -0.154 & 0.878 \\
\hline
\end{tabular}

* Statistically significant for the significance level of $0.05 ; * *$ Statistically significant for the significance level of 0.01

\section{The college variable}

As the variable of the college in this study is divided into two parts: human and scientific, therefore a t-test analysis was used to compare the averages of mental health degrees with their dimensions according to the college variable. Table 6 shows the result of t-test for the significance of the differences between the averages.

It is clear from Table 6 that there are no statistically significant differences between the mean levels of mental health degrees with their dimensions (obsessivecompulsive disorder, depression, interactive sensitivity, anxiety, physical symptoms, hostility, fear anxiety (phobia), mental health as a whole) among study members according to the college variable, where the significance levels were $(0.682,0.959,0.568,0.728,0.889,0.363$, $0.157,0.878)$ respectively, which are non-significant levels. Consequently, there are no differences between those who study in human colleges and those who study in scientific colleges in the levels of mental health degrees in their dimensions (obsessive-compulsive disorder, depression, reactive sensitivity, anxiety, physical symptoms, hostility, fear anxiety (phobia), and mental health as a whole). It seems that all students from human and scientific colleges have been equally exposed to the pressures caused by this virus in addition to the number of the sample population from the scientific faculty was small compared to the human colleges, and this effect may not affect the difference between them. 
Table 7. Analysis of the significance of the differences between the mean levels of mental health degrees in their dimensions according to the variable of social status

\begin{tabular}{|c|c|c|c|c|c|c|}
\hline Axis & Social status & $\mathrm{N}$ & Mean & Standard deviation & "t" value & Sig \\
\hline $\begin{array}{l}\text { Obsessive-compulsive } \\
\text { disorder }\end{array}$ & $\begin{array}{l}\text { Single } \\
\text { Married }\end{array}$ & $\begin{array}{l}156 \\
102\end{array}$ & $\begin{array}{l}0.790 \\
0.553\end{array}$ & $\begin{array}{l}0.695 \\
0.640\end{array}$ & 2.763 & $0.006^{* *}$ \\
\hline Depression & $\begin{array}{l}\text { Single } \\
\text { Married }\end{array}$ & $\begin{array}{l}156 \\
102\end{array}$ & $\begin{array}{l}1.174 \\
0.842\end{array}$ & $\begin{array}{l}0.805 \\
0.704\end{array}$ & 3.403 & $0.001 * *$ \\
\hline Interactive sensitivity & $\begin{array}{l}\text { Single } \\
\text { Married }\end{array}$ & $\begin{array}{l}156 \\
102\end{array}$ & $\begin{array}{l}0.890 \\
0.650\end{array}$ & $\begin{array}{l}0.814 \\
0.694\end{array}$ & 2.450 & $0.015^{*}$ \\
\hline Anxiety & $\begin{array}{l}\text { Single } \\
\text { Married }\end{array}$ & $\begin{array}{l}156 \\
102\end{array}$ & $\begin{array}{l}1.023 \\
0.706\end{array}$ & $\begin{array}{l}0.814 \\
0.684\end{array}$ & 3.256 & $0.001 * *$ \\
\hline Physical symptoms & $\begin{array}{l}\text { Single } \\
\text { Married }\end{array}$ & $\begin{array}{l}156 \\
102\end{array}$ & $\begin{array}{l}0.905 \\
0.506\end{array}$ & $\begin{array}{l}0.883 \\
0.661\end{array}$ & 3.907 & $0.000 * *$ \\
\hline Enmity & $\begin{array}{l}\text { Single } \\
\text { Married }\end{array}$ & $\begin{array}{l}156 \\
102\end{array}$ & $\begin{array}{l}0.687 \\
0.466\end{array}$ & $\begin{array}{l}0.698 \\
0.570\end{array}$ & 2.670 & $0.008 * *$ \\
\hline Phobia & $\begin{array}{l}\text { Single } \\
\text { Married }\end{array}$ & $\begin{array}{l}156 \\
102\end{array}$ & $\begin{array}{l}0.655 \\
0.472\end{array}$ & $\begin{array}{l}0.711 \\
0.560\end{array}$ & 2.188 & $0.030^{*}$ \\
\hline Mental health as a whole & $\begin{array}{l}\text { Single } \\
\text { Married }\end{array}$ & $\begin{array}{l}156 \\
102\end{array}$ & $\begin{array}{l}0.902 \\
0.616\end{array}$ & $\begin{array}{l}0.708 \\
0.600\end{array}$ & 3.353 & $0.001 * *$ \\
\hline
\end{tabular}

* Statistically significant for the significance level of $0.05 ; * *$ Statistically significant for the significance level of 0.01

\section{The social status variable}

As the college variable in this study is divided into two parts: single and married, therefore a t-test analysis was used to compare the averages of mental health degrees with their dimensions according to the variable of marital status. Table 7 shows the result of the t-test for the significance of the differences between the averages.

It is clear from Table 7 that there are statistically significant differences between the mean levels of mental health levels with their dimensions (obsessive-compulsive disorder, depression, interactive sensitivity, anxiety, physical symptoms, hostility, fear anxiety (phobia), mental health as a whole) among study members according to the variable of social status, where the significance levels were $(0.006,0.001,0.015,0.001$, $0.000,0.008,0.030,0.001)$ respectively and they are indicative levels. Thus, there are differences between single and married in average mental health degrees in their dimensions (obsessive-compulsive disorder, depression, reactive sensitivity, anxiety, physical symptoms, hostility, fear anxiety (phobia), mental health as a whole was low in single due to middle-level average of mental problems.

\section{DISCUSSION}

\section{The level of mental health among the study sample individuals}

In this study, the reason for the high level of mental health may be due to the educational measures taken by the university, such as distance learning and electronic exams that the university has trained students on, the atmosphere of study and exams was very comfortable, which reflected positively on their mental health. Also, the confidence of the sample members in the measures taken by the state to fight the virus and the strong commitment by all to the directions and instructions, which gave them a feeling of confidence, comfort, lack of anxiety and fear, and their lives going on naturally and comfortably. The study was also conducted in the month of Ramadan, which contributed positively to finding reassurance and serenity among the sample members, in addition to the normal course of life and the availability of food and medicine needed by the citizens which contributed effectively to this result. Also, the large number of psychological and social support programs on satellite channels and social media played an important role in the high level of mental health. The results indicate that the students enjoy a high level of mental health and this is consistent with the results of the (Belknduz 2017) and the (Meloidogyne \& Ajimi 2017) study, where these studies indicated that the students enjoy a high level of mental health. Also, this is consistent with the study of (Wenjun et al. 2020) that social support and the presence of the family helps to cope with the pandemic with more psychological strength.

\section{The differences in mental health scores according to the demographic variables (Gender)}

he results indicate that the level of mental health in females is lower compared to males and this is consistent with the (Eaton et al. 2012); While (Balkanders 2017) found that females enjoy a high level of psychological health compared to males, perhaps the reason is due to the restriction of movement and the inability to go out to shop at the beginning of the crisis and move away from seeing female friends as usual and what is known that females in Emirati society are largely committed. These additional restrictions on 
movement due to the pandemic made them more sensitive to the situation and more affected by the level of mental health.

\section{The differences in mental health scores according to the demographic variables (Academic level)}

The results indicate that the students of the second year are the ones who have had a low level of mental health compared to the rest of the students from other levels and this result may be attributed to the fact that students at this stage are at the crossroads and anxiety and fear have become clear to them more than others as they have made their way when they are at the end of the second year, and they would like to move to the third year, which indicates the beginning of the completion of university studies.

\section{The differences in mental health scores according to the demographic (Age variable)}

Students who were less than twenty years old had less mental health compared to those over twenty years old. Perhaps the reason is that this group is less experienced in life and fear than what may happen, and they have not yet experienced the joys of life. The older ones are more experienced and knowledgeable in dealing with matters and dealing with stress resulting from the spread of this virus.

\section{The differences in mental health scores according to the demographic variables (College variable)}

It seems that all students from human and scientific colleges have been equally exposed to the pressures caused by this virus in addition to the number of the sample population from the scientific faculty was small compared to the human colleges, and this effect may not affect the difference between them.

\section{The differences in mental health scores according to the demographic variables (Age variable)}

These are important and significant results, as married people are safer, more comfortable and more secure, which increases their psychological immunity, and thus the level of mental health is high compared to the category of singles who feel anxious and fearful about the future, as we have indicated previously, they have not experienced the lives of married people and were not yet captive, and this undoubtedly gives high comfort and mental health.

\section{The limitations of the study}

This study was restricted to Al Ain University students enrolled in the second semester of the year 20192020 from humanities and scientific colleges.

The study is limited to some demographic variables (gender, academic level, age, college, and marital status)

\section{CONCLUSIONS}

The results of this study, which was conducted at the time of the virus's invasion, are very important, especially as it sheds light on the effect of the virus on mental health, which gives good information to decision-makers in developing special policies and strategies to maintain the level of mental health among this segment of society, namely students. Also, this study is considered one of the few studies that dealt with this topic due to its novelty.

It is clear that the mental health level among the sample is very high as seen from the results.

The results of the study indicate that the higher the average mental problems (the dimensions of the mental health level), the lower the mental health level, and we have explained that previously. The results showed that the level of mental health was low for females compared to males, and the second-year students were less in the level of mental health compared to the rest of the levels. For students who were less than twenty years old, the level of mental health was low compared to those over twenty years old. No differences were found in the level of mental health among students of scientific and human colleges. As for the social situation, the level of mental health among single students was low compared to married people.

\section{Acknowledgements:}

\section{Recommendations}

Conducting a wider studies examining more demographic variables and dealing with different samples and comparing its results with the results of the current study.

- Developing special policies and strategies to maintain the level of mental health among this segment of society, namely students.

- Activating the university's counseling center to help students perform their academic and social roles successfully through a remote counseling meeting, providing more effective psychological counseling and conducting workshops and courses to strengthen psychological immunity, especially for the females, second-year students, and single students.

- Establishing programs in self-management that include positive ways to improve mental health.

\section{Conflict of interest : None to declare.}

\section{Contribution of individual authors:}

Youssef Abuhmaidan: conceptualized the project, contributed to data analysis, first manuscript draft, interpretation and manuscript development, study design, statistical analysis, approval of the final version.

Salwa Al-Majali: performed literature search,data collecion entry, manuscript revisions, approval of the final version. 


\section{References}

1. Abuhmaidan Y: Introduction to Personality Psychology. Amreya for publication and distribution; Jordan: Amman, 2019

2. Balkanduz Z: The reality of mental health among students of Abdul Hamid ben Badis University. Journal of Psychological and Educational Sciences 2017; 4:248-266

3. Eaton $R$ et al: An Invariant Dimensional Liability Model of Gender Differences in Mental Disorder Prevalence: Evidence from a National Sample. J Abnorm Psychol 2012; 121:282-288

4. Liu S, Yang L, Zhang C, Xiang Y, Liu Z, Hu S, Zhang B: Online Mental Health services in china during the COVID-19. The lance Psychiatry 2020; 7:17-18

5. McKay D, Yang H, Elhai J, Asmundson G: Anxiety Regarding Contracting COVID-19 Related to Interoceptive Anxiety Sensations. Journal of Anxiety Disorders 2020. doi:https://doi.org/10.1016/j.janxdis.2020.102233
6. Meloidogyne \& Ajimi K: The level of mental health of people with type 1 diabetes (subject to insulin). unpublished master thesis. Abdul Hamid ben Badis University, Algeria, 2017

7. Ohrnbergera J, Ficherab E \& Suttona M: The relationship between physical and mental health: A mediation analysis. Social Science \& Medicine Journal 2017; 195:42-49

8. Qabbani H: Introduction to mental health. University Book House, UAE: Al Ain, 2017

9. Radwan S: Mental Health. Dar Almaseera for publishing distribution, and printing. Jordan: Amman, 2002

10. Wenjun C, Ziwei F, Guooiang H, Mei H, Xinrong X, Jiaxin D, Jianzhong Z: The Psychological Impact of the COVID-19 Epidemic on College Students in China. Psychiatry Research 2010; 287:220-227

11. WHO: Corona virus advice for public? Available from 2019; https://www.who.int/emergencies/diseases/novelcoronavirus-2019. (Accessed on 14 April 2020)

Correspondence:

Prof. Youssef Abuhmaidan

Department of Humanities and Social Sciences, Al Ain University

P.O. Box 64141, Al Ain, UAE

E-mail: Yousef.abuhmaidan@aau.ac.ae 